\title{
RANCANG BANGUN SISTEM INFORMASI RENCANA ANGGARAN BIAYA (RAB) PERUSAHAAN BERBASIS WEB PADA PT. BUMITANGERANG MESINDOTAMA
}

\author{
Anita B. Wandanaya ${ }^{1}$, Andrian Wicaksono ${ }^{2}$ \\ ${ }^{1}$ Dosen STMIK Raharja Jurusan Teknik Informatika ${ }^{2}$ Mahasiswa STMIK Raharja Jurusan Sistem \\ Informasi \\ ${ }^{1,2}$ STMIK Raharja, J1. Jenderal Sudirman No. 40 Modern Cikokol - Tangerang \\ e-mail: ${ }^{1}$ anita@raharja.info, ${ }^{2}$ andrian@ raharja.info
}

\begin{abstract}
The cost budget plan is one of the controls in the management of a project that will be planned in the company, if in the planning of a project there is no budget plan then a project will be ambiguous in making the report, it also needs to be applied to PT. Bumitangerang Mesindotama to facilitate companies in planning the costs. Therefore, it is necessary to have a system that can produce output in the form of detailed reports for planning company budget costs in meeting the procurement system of a project plan. In this study a web-based system is implemented for planning project cost budgets in companies, therefore it is necessary to design a web-based company budget plan system. This system uses web-based input in the process of filling out project activities, details of required materials and budget planning of the required costs so that it can produce final reports in the form of the neat recapitulation. With the creation of a cost budget plan system is expected to solve existing problems and the company no longer needs to use a manual way to plan budget costs, so that the budget planning process can run more quickly and accurately. In this study, researchers used the System Development Life Cycle (SDLC) method which was supported by data collection through observation and literature study.
\end{abstract}

Keywords : Cost budget, business, Web

Abstrak

Rencana anggaran biaya merupakan salah satu pengendalian dalam pengelolaan sebuah proyek yang akan direncanakan pada perusahaan, jika didalam perencanaan sebuah proyek tidak ada rencana anggaran biayanya maka suatu proyek tersebut akan rancu dalam pembuatan laporannya, itu pula yang di rasakan perlu diterapkan pada PT. Bumitangerang Mesindotama untuk memudahkan perusahaan dalam merencanakan biaya yang ada. Oleh sebab itu, diperlukan sebuah sistem yang dapat menghasilkan output rekapan dalam bentuk rincian laporan untuk perencanaan anggaran biaya perusahaan dalam memenuhi sistem pengadaan sebuah perencanaan proyek. Dalam penelitian ini diimplementasikan sebuah sistem berbasis web untuk perencanaan anggaran biaya proyek pada perusahaan, maka dari itu perlu dirancang sebuah sistem rencana anggaran biaya perusahaan berbasis web. Sistem ini menggunakan input berbasis web dalam proses pengisian kegiatan proyek, rincian bahan yang diperlukan dan perencanaan anggaran biaya yang dibutuhkan sehingga dapat menghasilkan laporan akhir dalam bentuk rekapan yang rapih. Dengan dibuatnya sistem rencana anggaran biaya ini diharapkan dapat menyelesaikan masalah yang ada dan perusahaan tidak perlu lagi menggunakan cara manual untuk melakukan perencanaan anggaran biaya, sehingga proses perencanaan anggaran biaya dapat berjalan lebih cepat dan akurat. Dalam penelitian ini peneliti menggunakan metode Sistem Development life Cycle (SDLC) yang didukung dari pengumpulan data melalui observasi dan studi pustaka.

Keywords : Anggaran biaya, perusahaan, Web 


\section{PENDAHULUAN}

Pada zaman yang semakin maju ini banyak sekali aplikasi dan sistem informasi yang dibuat untuk menunjang dan menciptakan kemajuan di berbagai bidang dalam segala aktifitas yang dilakukan oleh manusia. Dengan hadirnya teknologi informasi banyak membuat kemudahan dalam mendapatkan informasi dan perhitungan yang cepat, tepat dan akurat.

Untuk mendapatkan perencanaan anggaran biaya yang akurat harus didukung pula dengan perhitungan yang baik. Terkadang perhitungan yang rumit dan membutuhkan waktu yang lama membuat seseorang malas untuk menghitung rencana anggaran biaya, sehingga perencanaan anggaran biaya menjadi tidak baik. Perencanaan anggaran biaya yang dilakukan secara manual juga dapat terjadi kesalahan perhitungan ataupun penulisan yang membuat perhitungan menjadi tidak akurat.

Oleh karena itu, dirasakan perlunya sistem terutama pada sebuah perusahaan agar dapat memudahkan dalam perencanaan anggaran biaya, dan juga dalam perhitungan biaya dapat berjalan lebih efektif, efisien dan akurat.

Sistem ini bekerja dengan memasukkan judul kegiatan serta perkiraan anggaran dalam melakukan kegiatan, dan memilih dari divisi yang memerlukan anggaran biaya tersebut. Setelah itu user harus merincikan uraian kegiatan yang akan dilaksanakan, lalu data-data tersebut dimasukkan ke dalam laporan kegiatan.

\section{METODOLOGI PENELITIAN}

Metode SDLC menggunakan pendekatan yang disebut pendekatan air terjun (waterfall approach), yang menggunakan beberapa tahapan dalam mengembangkan sistem. Tahap tersebut dinamakan waterfall karena pada setiap tahapan sistem akan dikerjakan secara berurut menurun dari satu ke tahap yang lain. Tahapan-tahapan metode penelitian SDLC sebagai berikut :

1. Tahap perencanaan sistem, tahap perencanaan adalah tahap awal pengembangan sistem yang mendefinisikan perkiraan kebutuhan sumber daya seperti perangkat fisik, manusia, metode (teknik dan operasi), dan anggaran yang sifatnya masih umum (belum rinci).

2. Analisa kebutuhan sistem, tahap analisa kebutuhan sistem merupakan tahap penelitian atas sistem yang telah ada dengan tujuan merancang sistem yang baru atau diperbaharui. Tahap ini merupakan tahap kritis dan sangat penting karena akan menentukan berhasil tidaknya sistem yang akan dibangun atau dikembangkan.

3. Perancangan sistem, tujuan pada tahap perancangan sistem adalah untuk memenuhi kebutuhan kepada para pemakai, serta memberikan gambaran yang jelas dan rancang bangun yang lengkap kepada pemrogram komputer dan ahli teknik lain yang terlibat.

4. Implementasi, tahap implementasi atau penerapan adalah tahap dimana desain sistem dibentuk menjadi suatu kode (program) yang siap untuk dioperasikan.

5. Tahap pemeliharaan merupakan tahap yang dilakukan setelah implementasi, yang meliputi pemakaian atau penggunaan, audit, penjagaan, perbaikan, dan peningkatan sistem. [1]

Rencana Anggaran Biaya (RAB) merupakan perhitungan banyaknya biaya yang diperlukan untuk bahan dan upah, serta biaya-biaya lain yang berhubungan dengan pelaksanaan proyek pembangunan. Secara umum perhitungan $\mathrm{RAB}$ dapat dirumuskan sebagai berikut: $\mathrm{RAB}=\sum$ (Volume $\mathrm{x}$ Harga Satuan Pekerjaan). [2]

\section{PERUMUSAN MASALAH}

Merencanakan suatu anggaran biaya adalah hal penting bagi perusahaan, bila perencanaan biaya perusahaan tersusun baik maka setiap proyek yang dikerjakan juga berjalan dengan baik. Pada umumnya jika perhitungan biaya tidak tersusun secara sistematis maka perencanaan anggaran biayapun akan rancu yang dapat mengakibatkan pengerjaan proyek menjadi terhambat.

Dari rumusan masalah yang ada dapat ditinjau beberapa masalah diantaranya :

1. Bagaimana proses pengolahan data dalam sistem Rencana Anggaran Biaya (RAB) ?

2. Bagaimana membuat Sistem Rencana Anggaran Biaya (RAB)?

3. Faktor apa saja yang diperlukan dalam perhitungan rencana anggaran biaya ?

4. Berbasis apa sistem Rencana Anggaran Biaya (RAB) dibuat ?

5. Manfaat apa yang bisa didapat dari pembuatan sistem Rencana Anggaran Biaya (RAB) ini ? 


\section{KAJIAN LITERATUR}

1. Penelitian ini dilakukan oleh Farouk Kusdony Muzaki, Arifin Puji Widodo, dan Romeo pada tahun 2014 dari STMIK Stikom Surabaya dalam bentuk Jurnal ilmiah yang berjudul "Rancangan Bangun Aplikasi Perencanaan Anggaran Biaya Tenaga Kerja Pada Proyek Konstruksi Gedung” penelitian ini membahas tentang sebuah aplikasi yang digunakan untuk menghitung kebutuhan tenaga kerja pada tiap kegiatan dan menampilkan rincian harga kebutuhan tenaga kerja untuk membangun gedung. Berdasarkan evaluasi hasil uji coba, aplikasi perencanaan anggaran biaya tenaga kerja pada proyek konstruksi gedung yang telah dibuat dapat menghitung kebutuhan tenaga kerja dalam kegiatan pembangunan gedung dan memberikan hasil rincian biaya tenaga kerja setiap kegiatan serta membantu perkiraan perhitungan sebagai acua biaya sebelum membangun gedung. [3]

2. Penelitian yang dilakukan oleh Sugiri pada tahun 2016 dari Sekolah Tinggi Teknologi Kedirgantaraan dalam bentuk Jurnal ilmiah yang berjudul "Pengembangan Aplikasi Perhitungan Biaya Instalasi Listrik Rumah Tinggal Berbasis Client-Server" penelitian ini membahas listrik yang merupakan faktor yang sangat penting dalam kehidupan manusia. Hampir semua orang membutuhkan listrik dalam kehidupan sehari-hari. Sebelum memasang listrik perlu dilakukan perencanaan yang matang sehingga bisa menyediakan tenaga listrik yang aman, efisien dan efektif. Pada penelitian ini dibuat pengembangan aplikasi berbasis client-server. Perangkat lunak (software) yang digunakan adalah sistem operasi microsoft windows xp profesional, database server mysql, visual basic 6.0 dan crystal report 8.5. Hasil pengembangan berupa aplikasi yang dapat digunakan untuk menghitung biaya listrik rumah tinggal. [4]

3. Penelitian yang dilakukan oleh Yopi Ratna Dewanti pada tahun 2016 dari Lembaga Pendidikan dan Pengembangan Profesi Indonesia (LP3I) dalam bentuk jurnal ilmiah yang berjudul "Peranan Anggaran Sebagai Alat Perencanaan dan Pengendalian Suatu Tinjauan Konseptual Atas Sistem Anggaran Lembaga Pendidikan dan Pengembangan Profesi Indonesia (LP3I) Tangerang". Penelitian ini membahas tentang penyusunan anggaran pada LP3I tangerang yang berdasarkan dari rencana kerja yang disusun oleh masing masing kelompok unit kerja dalam Rakercab (Rapat Kerja Cabang) dan kemudian dikonsolidasikan pada tingkat pusat (LP3I pusat). Pengendalian anggaran di LP3I Tangerang selalu mengadakan penilaian terhadap kinerja masing-masing fungsi/unit yang ada melalui pertanggungjawaban anggaran. Setiap penyimpangan yang signifikan diminta penjelasan mengenai sebab-sebab terjadinya, sehingga dapat dilakukan perbaikan secara dini. Pada akhir tahun dilakukan lagi evaluasi terhadap realisasi seluruh rencana kerja dan anggaran untuk menilai prestasi kerja suatu fungsi. Selain sebagai alat pengendalian intern, laporan realisasi anggaran dan analisanya, juga sebagai sarana pertanggungjawaban manajer cabang tangerang kepada direktur keuangan LP3I pusat. Tujuan dari penelitian yang dilakukan oleh penulis adalah untuk mengetahui peranan anggaran dalam penyusunan program perusahaan dan untuk mengetahui manfaat anggaran dalam rangka pengendalian operasional di LP3I tangerang. [5]

4. Penelitian ini dilakukan oleh Indra Faisol Alim pada tahun 2016 dari Universitas Islam Negeri Sunan Kali Jaga dalam bentuk laporan Skripsi yang berjudul "Rancangan Bangun Aplikasi Rencana Anggaran Biaya (RAB) Untuk Bangunan Sederhana Di Yogyakarta Berbasis Android Dengan Metode Extreme Programming" penelitian ini membahas tentang sebuah aplikasi yang digunakan untuk menghitung RAB (rencana anggaran biaya) yang dibutuhkan baik upah maupun bahan dalam sebuah pekerjaan proyek konstruksi. Pada aplikasi ini disajikan beberapa fitur antara lain form untuk pengisian luasan pada pengerjaan arsitektural seperti: pengerjaan lantai, pengerjaan dinding, pengerjaan atap serta pengerjaan kayu. Untuk pendefinisian rangka ada pada pengerjaan struktural, diamana terdapat empat pilihan menu yang harus diisi seperti pondasi, kolom, balok serta rangka. [6]

\section{HASIL DAN PEMBAHASAN}

Untuk mengatasi masalah di atas, maka diperlukan beberapa alternatif pemecahan dari permasalahan yang dihadapi, antara lain : 
1. Dapat dibuatkan sistem yang memudahkan perhitungan rencana anggaran biaya pada sebuah PT. Bumitangerang Mesindotama.

2. Dapat memberikan hasil kesimpulan perhitungan rencana anggaran biaya, uraian kegiatan, serta laporan permintaan anggaran biaya.

3. Dapat mengeluarkan hasil rencana anggaran biaya yang berupa PDF.

\section{Tabel Rencana Anggaran Biaya (RAB) Perusahaan}

Rencana anggaran biaya adalah perencanaan suatu biaya mulai dari bahan baku yang digunakan hingga biaya jasa untuk mengetahui berapa biaya total yang diperlukan untuk pengerjaan sebuah proyek.

Untuk mengetahui susunan laporan untuk keperluan anggaran biaya pada perusahaan, maka dibuatlah sebuah tabel Rencana Anggaran Biaya (RAB) yang berisikan, Jenis kegiatan, Divisi, Uraian, Satuan, Jumlah, Harga satuan dan Total biaya.

\section{Contoh Tabel Rencana Anggaran Biaya Perusahaan}

Jenis Kegiatan : Pemasangan CCTV

Divisi : IT

\begin{tabular}{|c|c|c|c|c|c|}
\hline No & URAIAN & Satuan & Jumlah & $\begin{array}{c}\text { Harga Satuan } \\
\text { (Rp) }\end{array}$ & Total Biaya \\
\hline (1) & (2) & (3) & (4) & (5) & $(6)=(4) \times(5)$ \\
\hline \multirow[t]{12}{*}{1} & BAHAN & & & & \\
\hline & 1. Kamera CCTV & Per Unit & 6 & $\begin{array}{ll}\text { Rp. } & 575.000\end{array}$ & $\begin{array}{r}\text { Rp. } \\
3.450 .000\end{array}$ \\
\hline & 2.Kabel Coaxial & Per Roll & 1 & $\begin{array}{ll}\text { Rp. } & 400.000\end{array}$ & $\begin{array}{r}\text { Rp. } \\
400.000\end{array}$ \\
\hline & 3.DVR CCTV & Per Unit & 1 & Rp. 1.500 .000 & $\begin{array}{r}\mathrm{Rp} . \\
1.500 .000\end{array}$ \\
\hline & 4.Isolasi Listrik & Per Biji & 2 & $\begin{array}{ll}\text { Rp. } & 12.000\end{array}$ & $\begin{array}{r}\text { Rp. } \\
24.000\end{array}$ \\
\hline & 5.Kabel listrik & Per Roll & 2 & $\begin{array}{ll}\text { Rp. } & 100.000\end{array}$ & $\begin{array}{r}\text { Rp. } \\
200.000\end{array}$ \\
\hline & 6.Klem Kabel No. 8 & Per Bungkus & 10 & Rp. $\quad 8.000$ & $\begin{array}{r}\text { Rp. } \\
80.000\end{array}$ \\
\hline & 7.Klem Kabel No. 14 & Per Bungkus & 5 & $\begin{array}{ll}\text { Rp. } & 10.000\end{array}$ & $\begin{array}{r}\mathrm{Rp} . \\
50.000 \\
\end{array}$ \\
\hline & 8.Kabel Tears & Per Bungkus & 1 & Rp. $\quad 30.000$ & $\begin{array}{r}\text { Rp. } \\
30.000\end{array}$ \\
\hline & $\begin{array}{l}\text { 9. Terminal listrik } \\
\text { Lubang } 4\end{array}$ & Per Biji & 4 & $\begin{array}{ll}\text { Rp. } & 12.000\end{array}$ & $\begin{array}{r}\text { Rp. } \\
48.000 \\
\end{array}$ \\
\hline & $\begin{array}{l}\text { 10. Terminal Listrik } \\
\text { Lubang } 2\end{array}$ & Per Biji & 2 & Rp. $\quad 8.000$ & $\begin{array}{r}\text { Rp. } \\
16.000\end{array}$ \\
\hline & \multicolumn{4}{|c|}{ Sub Total Upah (1) } & $\begin{array}{r}\text { Rp. } \\
5.798 .000 \\
\end{array}$ \\
\hline \multirow[t]{5}{*}{2} & ALAT BANTU & & & & \\
\hline & 1.Konfigurasi CCTV & Per Set & 1 & $\begin{array}{ll}\text { Rp. } \quad 500.000\end{array}$ & $\begin{array}{r}\text { Rp. } \\
500.000 \\
\end{array}$ \\
\hline & 2.Jasa Instalasi & Per Titik & 6 & Rp. $\quad 300.000$ & $\begin{array}{r}\text { Rp. } \\
1.800 .000 \\
\end{array}$ \\
\hline & \multicolumn{4}{|c|}{ Sub Total Bahan (2) } & $\begin{array}{r}\mathrm{Rp} . \\
2.300 .000 \\
\end{array}$ \\
\hline & \multicolumn{4}{|c|}{ Jumlah Total Biaya $(1+2)$} & $\begin{array}{r}\mathrm{Rp} . \\
8.098 .000 \\
\end{array}$ \\
\hline
\end{tabular}




\section{Analisa Prosedur}

Prosedur adalah kegiatan yang sesuai dari berbagai macam tahapan-tahapan yang berupa instruksi yang harus dilakukan oleh seseorang.

Prosedur dalam perencenaan anggaran biaya :

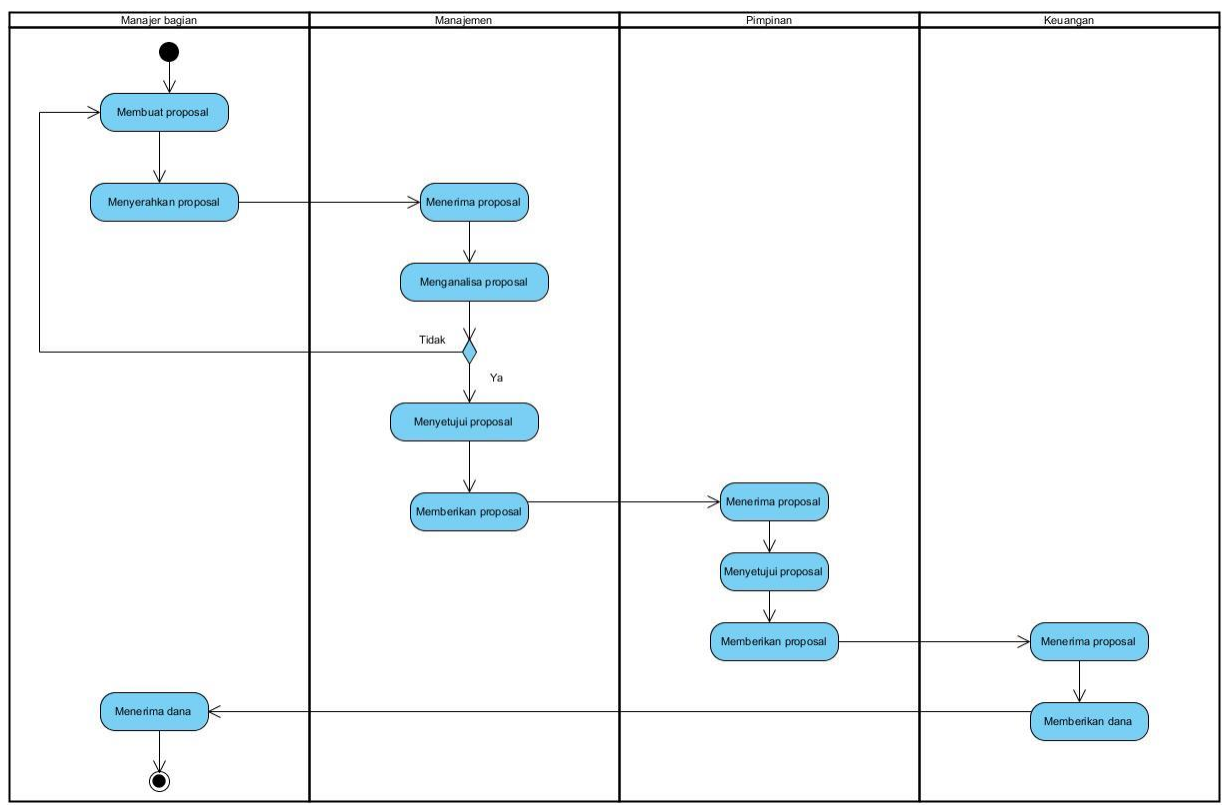

Gambar 1. Diagram Prosedur Perencanaan Anggaran Biaya

1. Manajer bagian membuat proposal rencana anggaran biaya

2. Proposal diserahkan kepada manajemen

3. Manajemen menganalisa proposal

4. Jika isi proposal sesuai maka disetujui oleh manajemen jika tidak dikembalikan ke manajer bagian

5. Proposal diserahkan kepada pimpinan untuk disetujui

6. Proposal diserahkan kepada bagian keuangan untuk mencairkan dana sesuai dengan proposal

7. Dana diberikan kepada manajer bagian yang membuat proposal

\section{Perancangan sistem}

Sistem yang dibuat adalah sistem perencanaan anggaran biaya yang dapat menghitung biaya berdasarkan inputan dari user serta dapat memberikan rincian kegiatan dan semua akan dimuat didalam sebuah laporan proyek, sistem ini dibuat dengan pemrograman berbasis web yaitu PHP, HTML, CSS dan database MySQL. Sistem ini dibangun dari beberapa struktur modul sebagai berikut :

1. Menu Login

2. Menu Utama

3. Menu Proyek

4. Menu Rincian

5. Menu Uraian Kegiatan

6. Menu Laporan 


\section{Use Case Diagram}

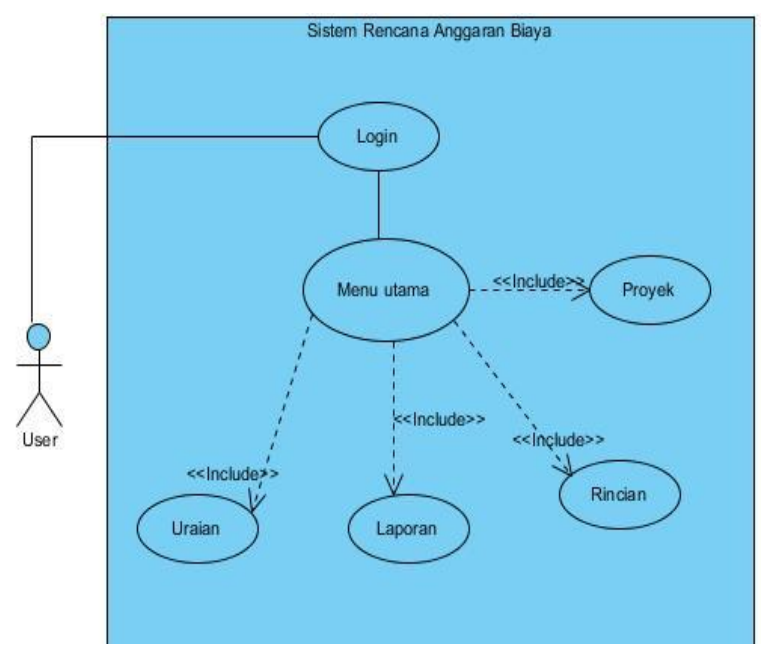

Gambar 2. Use Case Diagram Sistem Rencana Anggaran Biaya

Pada use case diatas, maka dapat mendeskripsikan berbagai kegiatan sebagai berikut :

1. User merupakan aktor

2. User mengakses halam web dan melihat menu login

3. User memasukan username dan password untuk masuk kemenu utama

4. User memilih menu proyek dan menginput judul proyek dan divisi

5. User memilih menu rincian dan memilih proyek yang akan dirincikan lalu menginput bahan, satuan, jumlah, dan harga

6. User memilih menu uraian dan memilih proyek yang akan diuraikan kegiatannya lalu menginputkan tanggal dan kegiatan yang dilakukan

7. User memilih menu laporan untuk melihat rekapan laporan proyek apa saja yang telah dilakukan

\section{Activity Diagram}

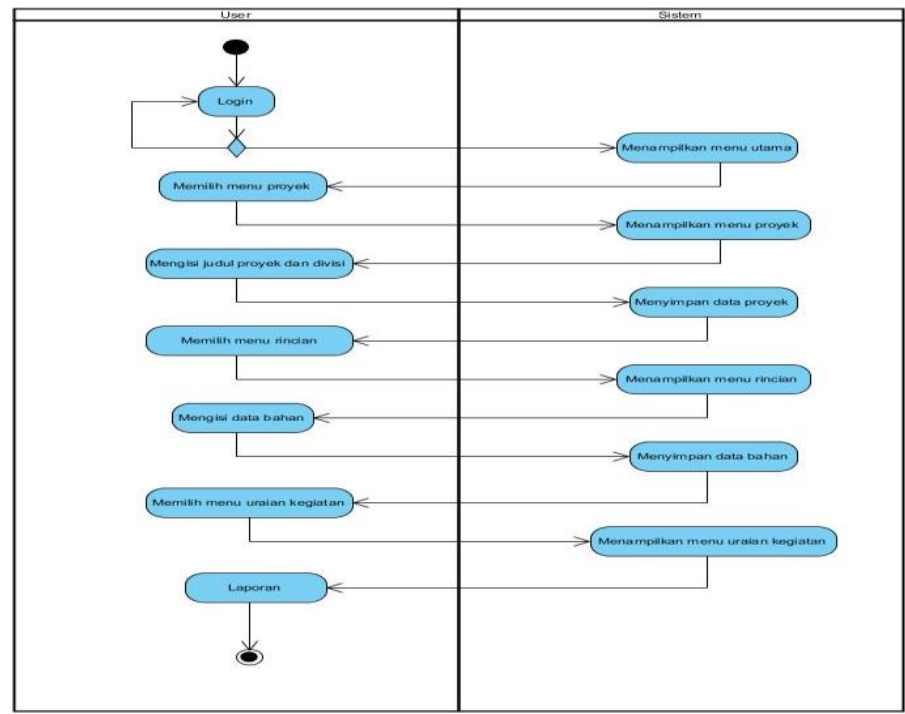

Gambar 3. Activity Diagram Sistem Rencana Anggaran Biaya

Pada activity diagram diatas, maka dapat mendeskripsikan hal-hal sebagai berikut :

1. User melakukan login

2. Jika login sukses maka sistem menampilkan menu utama jika tidak maka user kembali kemenu login 
3. User memilih menu proyek dan menginputkan data proyek seperti judul dan divisi

4. Sistem memproses dan menyimpan data proyek

5. User memilih menu rincian dan menginputkan data rincian seperti bahan, satuan, jumlah, dan harga

6. Sistem memproses dan menyimpan data rincian

7. User menu uraian dna menginputkan data uraian kegiatan seperti tanggal dan kegiatan yang dilakukan

8. Sistem memproses dan menyimpan data uraian

9. User memilih menu laporan dan memilih laporan yang ingin ditampilkan

10. Sistem menampilkan laporan

\section{Class Diagram}

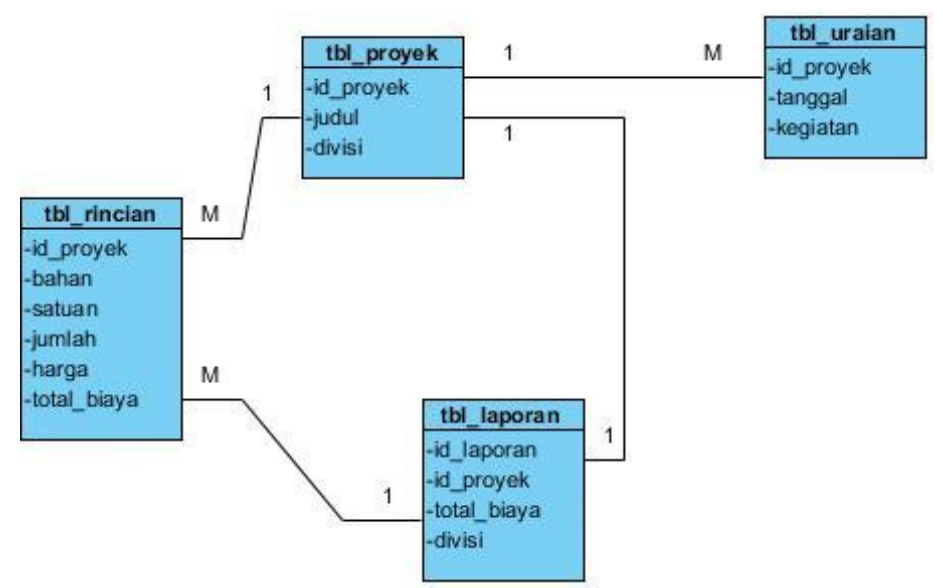

Gambar 4. Class Diagram Sistem Rencana Anggaran Biaya

Pada class diagram diatas, maka dapat mendeskripsikan rincian database sebagai berikut :

1. Class/table proyek memiliki relasi dengan rincian karena sebelum merincikan bahan yang diperlukan harus memilih proyeknya.

2. Class/ table rincian memiliki relasi dengan laporan karena laporan memerlukan data total biaya.

3. Class/ table laporan memilki relasi dengan proyek karena laporan memerlukan data proyek seperti judul dan divisi.

4. Class/ table proyek memilki relasi dengan uraian karena sebelum menguraikan kegiatan harus memilih proyeknya.

\section{PROTOTYPE TAMPILAN}

Dari hasil gambaran diagram yang ada dapat dibuatkan kedalam sebuah protoype tampilan sistem rencana anggaran biaya untuk memberikan penjelasan terhadap sistem rencana anggaran biaya yang berbasis web ini :

\section{Prototype Tampilan Menu Login}

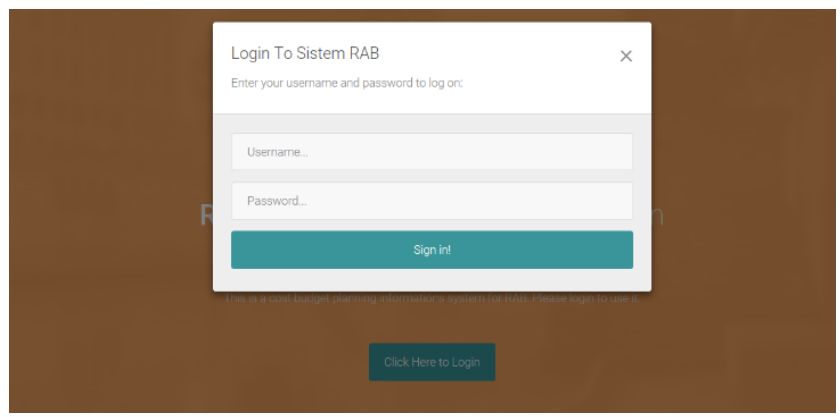

Gambar 5. Prototype Tampilan Menu Login 
Gambar 5. Merupakan prototype tampilan menu login sistem rencana anggaran biaya. User dapat memasukkan username dan password untuk melakukan login.

Pada tampilan ini user dapat melakukan login untuk menggunakan sistem rencana anggaran biaya, dengan memasukkan username dan password yang telah terdaftar.

Username : Tampilan ini User dapat mengisi username yang digunakan untuk melakukan login. Password : Tampilan ini User dapat mengisi password yang digunakan untuk melakukan login.

\section{Prototype Tampilan Menu Utama}

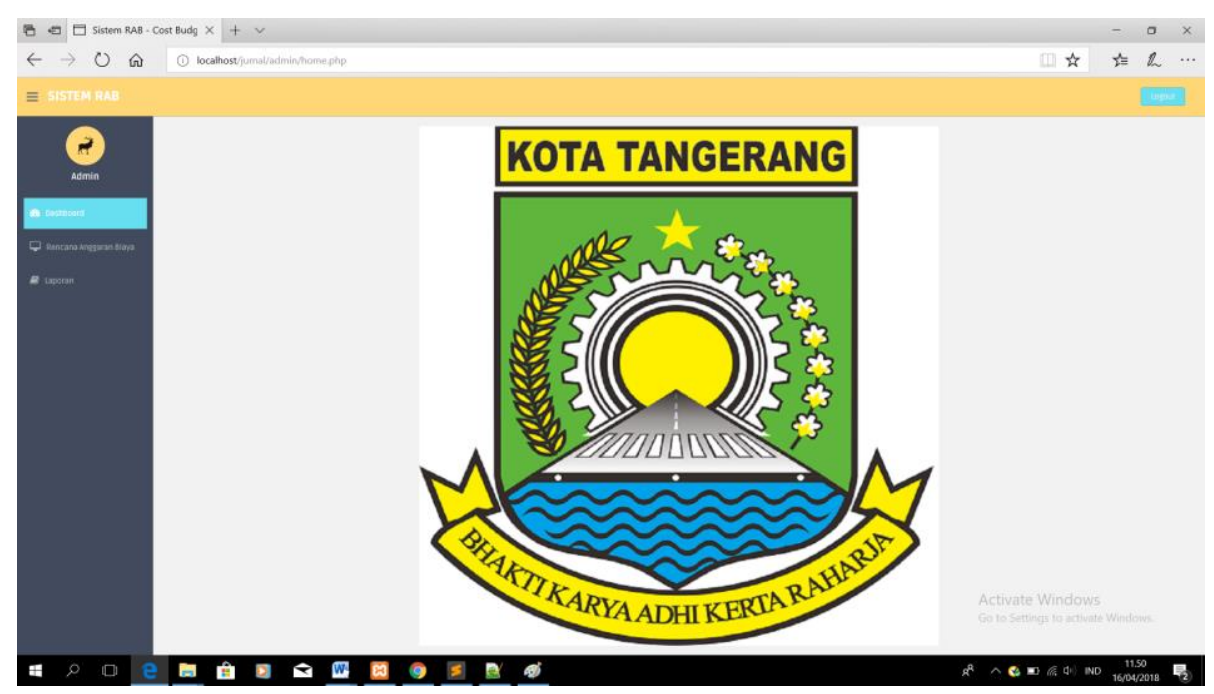

Gambar 6. Prototype Tampilan Menu Utama

Gambar 6. Merupakan prototype tampilan menu utama sistem rencana anggaran biaya.

Dengan adanya tampilan dashboard ini menunjukkan bahwa user telah berhasil melakukan login.

\section{Prototype Tampilan Menu Proyek}

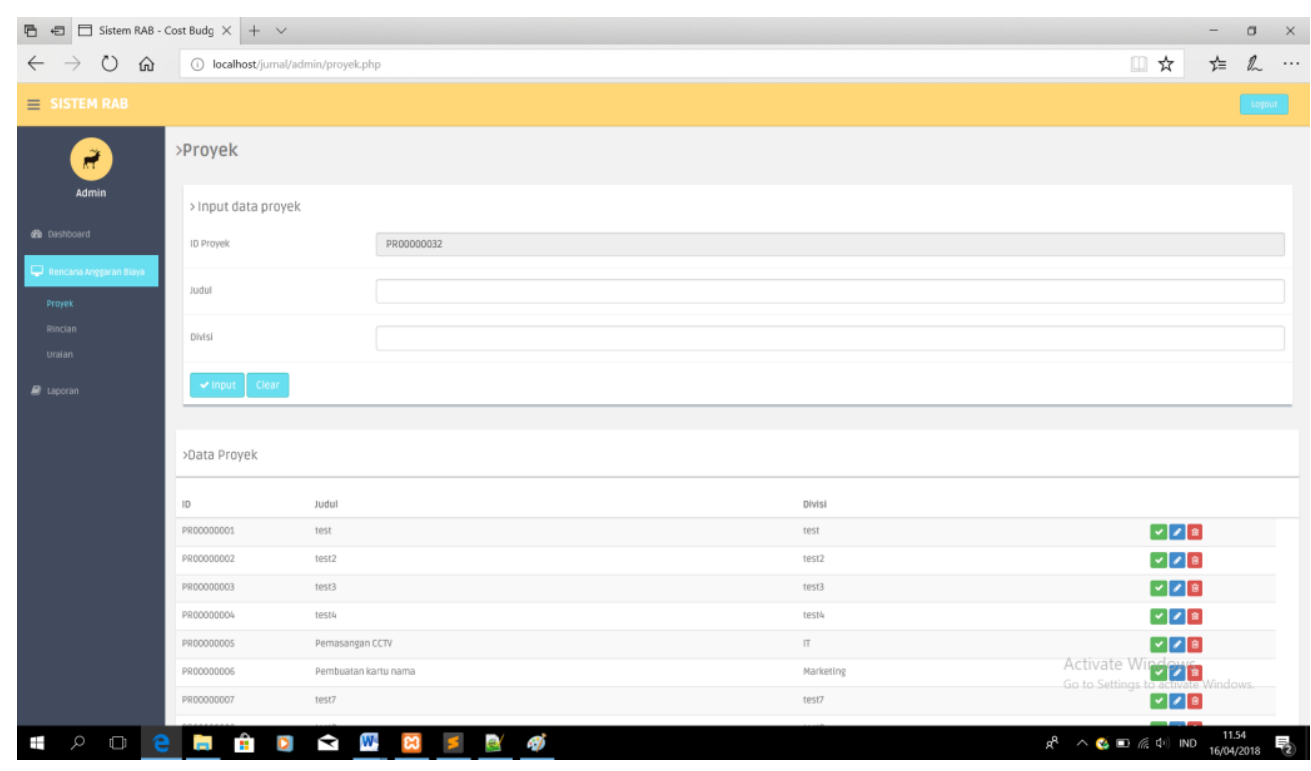

Gambar 6. Prototype Tampilan Menu Proyek 
Gambar 6. Merupakan prototype tampilan menu proyek pada sistem rencana anggaran biaya ini, setelah user memilih menu. Tampilan ini user dapat menginput judul proyek, dan dari divisi mana yang akan melaksanakan proyek dan juga menampilkan hasil dari seluruh data yang telah diinput. Judul proyek : Pada inputan ini user dapat mengisi judul proyek yang akan dilakukan.

Divisi : Pada inputan ini user dapat mengisi dari bagian mana yang meminta proyek.

\section{Prototype Tampilan Menu Rincian}

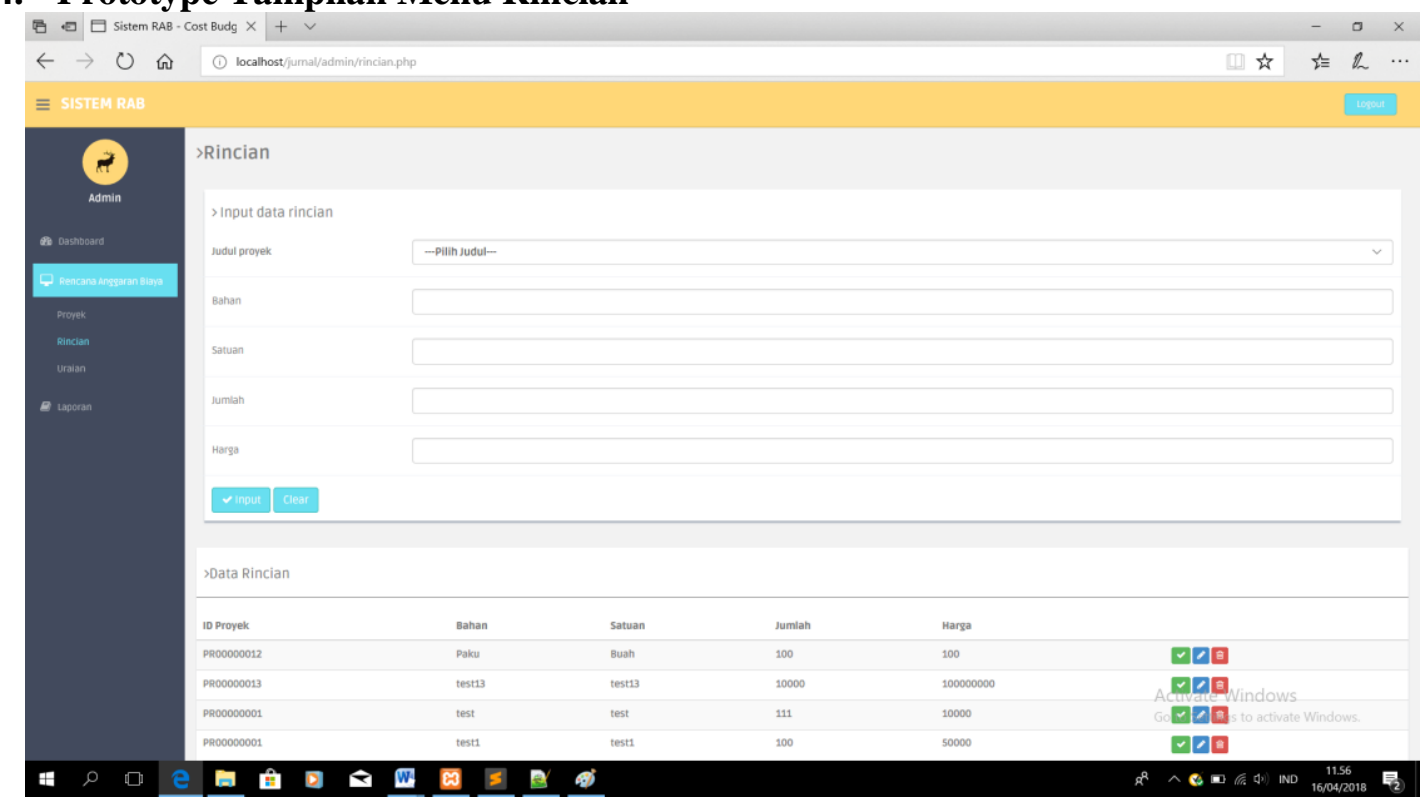

Gambar 7. Prototype Tampilan Menu Rincian

Gambar 7. Merupakan prototype tampilan menu rincian pada sistem rencana anggaran biaya ini, setelah user memilih menu tersebut.

Tampilan ini user dapat menginputkan bahan-bahan yang digunakan pada sebuah proyek, dan satuan, serta jumlah dan harga yang diperlukan pada sebuah proyek yang akan diadakan dan juga akan menampilkan hasil dari seluruh data yang diinput.

Proyek : Pada inputan ini user dapat memilih proyek mana yang akan diisi rincian dari bahan bakunya Bahan : Pada inputan ini user dapat mengisi bahan yang digunakan pada proyek

Satuan : Pada inputan ini user dapat mengisi satuan yang digunakan untuk bahan Jumlah : Pada inputan ini user dapat mengisi jumlah dari bahan yang digunakan pada proyek Harga : Pada inputan ini user dapat mengisi harga dari bahan

\section{Prototype Tampilan Menu Uraian}

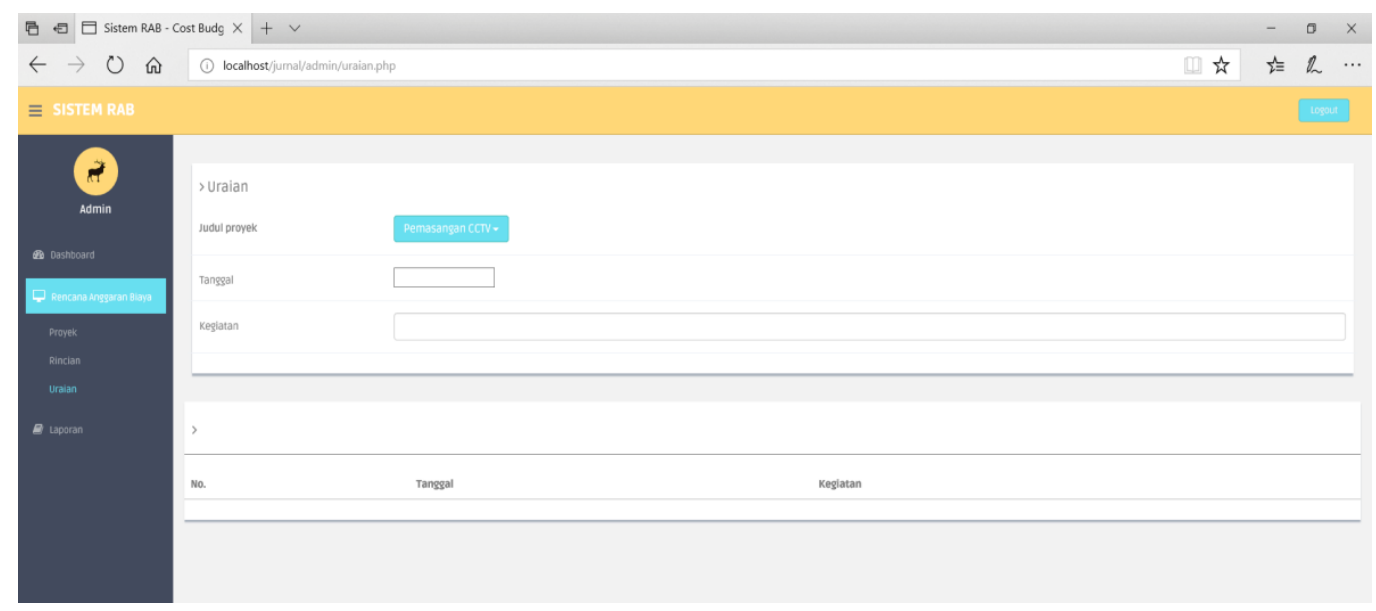

Gambar 8. Prototype Tampilan Menu Uraian 
Gambar 8. Merupakan prototype tampilan menu uraian pada sistem rencana anggaran biaya ini, setelah user memilih menu tersebut. Tampilan ini user dapat menginputkan tanggal dan kegiatan yang dilakukan selama proyek berlangsung dan juga menampilkan hasil dari seluruh data yang diinput. Proyek : Pada inputan ini user dapat memilih proyek mana yang akan diisi uraian kegiatan Tanggal : Pada pilihan ini user dapat memilih tanggal dari kegiatan yang dilakukan pada proyek Kegiatan : Pada inputan ini user dapat mengisi kegiatan yang dilakukan pada proyek

6. Prototype Tampilan Menu Laporan

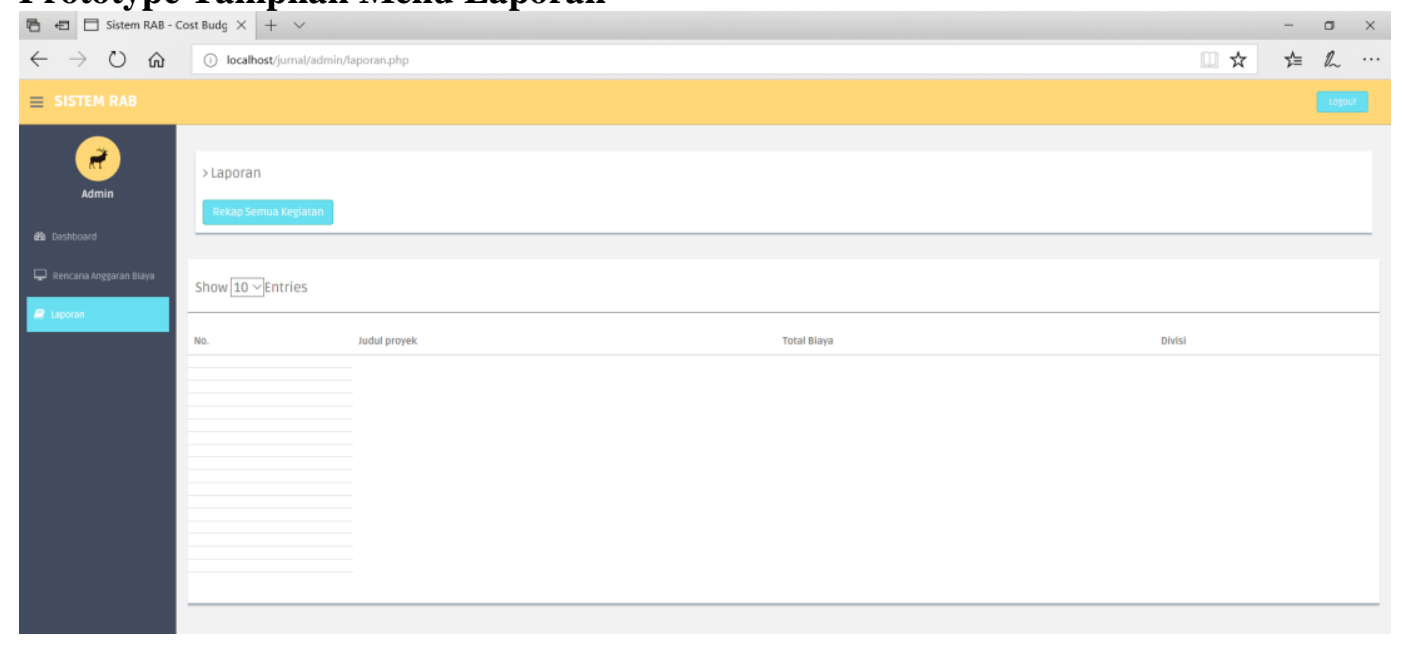

Gambar 9. Prototype Tampilan Menu Laporan

Gambar 9. Merupakan prototype tampilan menu laporan pada sistem rencana anggaran biaya ini, setelah user memilih menu tersebut. Tampilan ini menampilkan rekap semua kegiatan yang telah dilakukan dan juga menampilkan laporan berbentuk pdf.

Rekap semua proyek : Pada pilihan menu ini user dapat merekap semua laporan kedalam bentuk file pdf.

\section{KESIMPULAN}

Berdasarkan hasil pembahasan mengenai sistem rencana anggaran biaya diatas dapat disimpulkan, sebagai berikut:

1. Proses pengolahan data pada sistem rencana anggaran biaya yaitu dengan memasukkan judul proyek dan dari divisi mana yang membuat proyek lalu membuat rincian bahan apa yang digunakan juga memasukan jumlah dan harganya kemudian membuat uraian kegiatan selama proyek berlangsung agar penggunaan dana lebih transparan.

2. Sistem ini dibuat dengan bahasa pemrograman web yaitu html, php, css, dengan menggunakan sublime text sebagai code editor dan xampp sebagai all in one package yang terdiri dari web server dan database server

3. Ada beberapa faktor yang perlu diperhitungkan dalam memperhitungkan rencana anggaran biaya yaitu: bahan apa saja yang digunakan, dengan satuan apa membelinya, berapa jumlahnya, dan berapa harganya.

4. Sistem rencana anggaran biaya ini dibuat berbasis web agar penggunaannya lebih praktis, dengan hanya menggunakan perangkat yang memiliki web browser untuk membukanya

5. Dengan dibuatnya sistem ini diharapkan dapat mengatasi berbagai masalah dari sistem sebelumnya yang belum terkomputerisasi seperti kesalahan dalam penulisan ataupun perhitungan. 


\section{DAFTAR PUSTAKA}

[1] Ramadhan taufik, Utomo.V.G . 2014. “Rancang Bangun Aplikasi Mobile Untuk Notifikasi Jadwal Kuliah Berbasis Android (Studi Kasus : STMIK Provisi Semarang)”. Semarang : STMIK Provisi.

[2] Aris Juliyono. 2014. "Rancangan bangun Sistem Informasi Rencana Anggaran Biaya Pada CV. Hikmah Utama”. Surabaya : STIKOM

[3] Muzaki.F.K, Widodo.A.P, Romeo. 2014. "Rancangan Bangun Aplikasi Perencanaan Anggaran Biaya Tenaga Kerja Pad Proyek Konstruksi Gedung”. Surabaya: STMIK Stikom.

[4] Sugiri. 2016. "Pengembangan Aplikasi Perhitungan Biaya Instalasi Listrik Rumah Berbasis ClientServer. Yogyakarta: Sekolah Tinggi Teknologi Kedirgantaraan.

[5] Dewanti.Y.R. 2016. "Peranan Anggaran Sebagai Alat Perencanaan Dan Pengendalian Suatu Tinjauan Konseptual Atas Sistem Anggaran Lembaga Pendidikan Dan Pengembangan Profesi Indonesia (LP3I) Tangerang”. Tangerang : Lembaga Pendidikan Dan Pengembangan Profesi Indonesia (LP3I).

[6] Alim.I.F. 2016. Rancangan Bangun Aplikasi Rencana Anggaran Biaya (RAB) Untuk Bangunan Sederhana Di Yogyakarta Berbasis Android Dengan Metode Extreme Programming. Yogyakarta: Universitas Islam Negeri Sunan Kali Jaga. 